\title{
Structure, Composition and Spatial Distribution of Tree Species in a Remnant of the Semideciduous Seasonal Alluvial Forest of the Upper Paraná River Floodplain.
}

\author{
João Batista Campos ${ }^{* 1}$, Mariza Barion Romagnolo and Maria Conceição de Souza ${ }^{2}$ \\ ${ }^{I}$ Instituto Ambiental do Paraná, Av.Bento Munhoz da Rocha Neto, 16 - CEP 87.030-010 - Maringá - PR, Brazil. \\ ${ }^{2}$ Universidade Estadual de Maringá/PEA, Av. Colombo 5.790, CEP 87.020-900 - Maringá - PR, Brazil
}

\begin{abstract}
The aim of this investigation was to study the structure, distribution patterns, and dynamics of tree species in a remnant of the Semideciduous Seasonal Alluvial Forest in the Upper Paraná River Floodplain, Brazil. Spatial variation of the vegetation was considered mainly in relation to soil and topographic characteristics. The 5,946 $\mathrm{m}^{2}$ study area extended along a transect from the bank of the Paraná River across the floodplain, passing through a lake. Phytosociological analysis were performed for 36 plots, each $150 \mathrm{~m}^{2}$. Subanalysis were performed for $300 \mathrm{~m}^{2}$ zones. Soil characteristics and topographic profile and their relationship to the vegetation were analyzed. Hydrodynamic and sediment processes were the most important factors in vegetation establishment and succession, determining species selection and formation and evolution of the substrate. These processes and their local spatial variability fundamentally affected the dynamics, structure, and patterns of distribution.
\end{abstract}

Key words: alluvial forest, floristic distribution, hidrodynamic, phytosociology, riparian forest

\section{INTRODUCTION}

The floodplain of the Upper Paraná River, in the stretch between Itaipu Reservoir and the Porto Primavera Dam, is $3,375 \mathrm{~km}^{2}$ in area (FUEM/CIAMB-PADCT, 1993). This will be the last wild stretch of the Paraná River within the territory of Brazil after the closure of the Porto Primavera Dam, scheduled for 1999. Located in the original region of the Semideciduous Seasonal Forest (IBGE, 1992), the local vegetation is dominated by areas of Pioneer Formation (várzea or vegetation in areas subject to flooding), interspersed with areas of Alluvial Forest (Campos \& Souza, 1997). This region can be considered an ecotone or area of ecological tension, between the Semideciduous Seasonal Forest in the State of Paraná, and the Savanna (Cerrado) in the State of Mato Grosso do Sul.

In the course of settlement of the region, the forests were nearly decimated and less than $1 \%$ of the original forest cover remains (Ipardes, 1992; Fundação SOS Mata Atlântica, 1990). In the face of this alarming situation and because of the environmental importance of the area, the Federal Environmental Protection Area in the Upper Paraná River Floodplain was created. The establishment of conservation units is the first step in protecting an area and may be considered official recognition of its environmental importance. Concomitant action to protect and restore a particular ecosystem then becomes fundamental in guaranteeing its effective conservation, and it is incumbent upon the technical/scientific community to develop the necessary information.

The structure and floristic composition of the vegetation of the Upper Paraná River Floodplain has been studied by several investigators (Assis, 1991; Romagnolo et al., 1994; Souza \& Monteiro, 1996; Campos \& Souza, 1997; and others). Nevertheless, there is a lack of studies on the relationship between some of the key environmental factors and the structure and floristic composition of the different vegetation types which can be distinguished on these highly dynamic floodplain.

\footnotetext{
* Author for correspondence
} 
The objective of the present study was to generate information on the structure, distribution patterns, and composition of the tree species in relation to variations in the physical space, principally the soils and local topographic characteristics, in order to support actions to protect and restore the environment.

\section{MATERIALS AND METHODS}

\section{Study Area}

The floodplain of the Upper Paraná River extends from the debouchement of the Sucuriú and Tietê rivers into the Paraná to the Piquirí alignment (Maack, 1981), in the area influenced by Itaipu
Reservoir. After closure of the Porto Primavera Dam, scheduled for $1999,40 \%$ of the plain will be inundated, the other $60 \%$ (about $3,375 \mathrm{~km}^{2}$ ) will remain as the last remnant of this ecosystem and the only wild stretch of the Paraná River within the territory of Brazil. (Agostinho \& Zalewski, 1996).

The regional climate is classified according to the system of Köppen as Cfa, i.e. a climate with warm summers, the temperature of the warmest month above $22^{\circ} \mathrm{C}$ and an annual mean temperature of $22^{\circ} \mathrm{C}$. The mean annual precipitation is 1,200 to $1,300 \mathrm{~mm}$. (Eletrosul, 1986). The altitude is approximately $250 \mathrm{~m}$ above mean sea level (Campos \& Costa-Filho, 1994) (Fig.1).

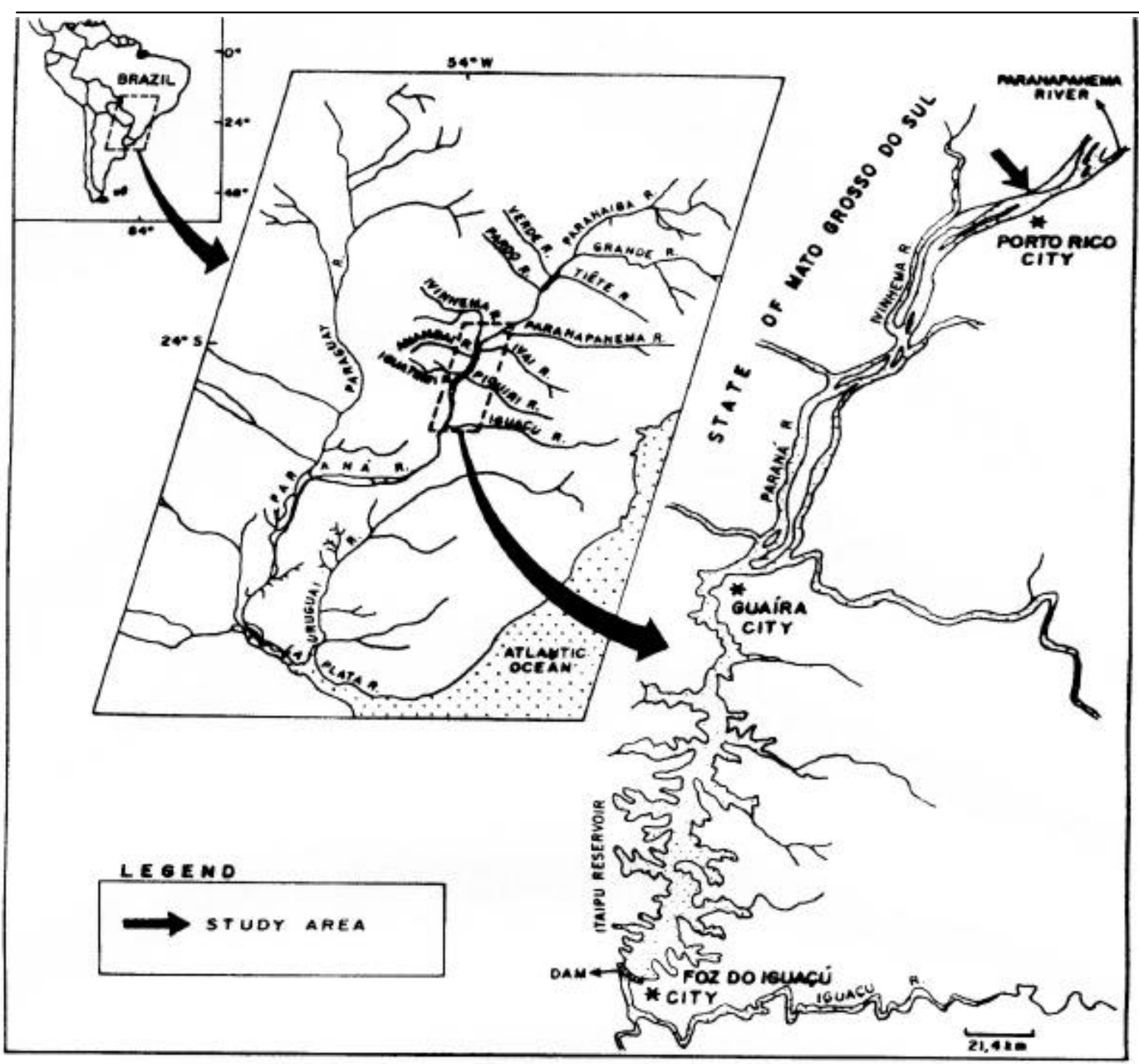


Figure 1 - Location of the study area in the Upper Paraná River Floodplain, Brazil.

For the present study, an area was selected, based on historical aerial photographs of the region and other information obtained from long-term local residents, which apparently had not been cut over or suffered other severe human disturbances. The chosen area is located on the right bank of the Paraná River in the Mato Grosso do Sul State, Brazil $\left(53^{\circ} 18^{\prime} \mathrm{W}, 22^{\circ} 43^{\prime} \mathrm{S}\right)$. It constitutes a remnant of the Semideciduous Seasonal Alluvial Forest (IBGE, 1992), and is bounded on one side by the Paraná River and on the other by the floodplain (Campos \& Souza, 1997).

\section{Methods}

In order to measure the slope of the transect, we used a hose level attached to a graduated rule. The soil was classified in accordance with Embrapa (1984), using a manual borer or by opening small trenches. The composition species was evaluated in regard to floristic richness and diversity and the structure of the vegetation was evaluated in regard to phytosociology (frequency, density, and dominance), basal area and number of individuals. This evaluation was performed based on phytosociological sampling, by means of the plot method (Müller-Dombois \& Ellenberg, 1974). The plots were arranged along a $198.20 \mathrm{~m}$ transect perpendicular to the river, in $30 \mathrm{~m}$ parallels, passing through a lake and comprising a total sample area of $5,400 \mathrm{~m}^{2}$ (Fig. 2).

All individual trees with $\mathrm{CBH}$ (circumference at breast height, measured at $1.30 \mathrm{~m}$ above ground level) equal or greater than $15 \mathrm{~cm}$, were sampled.
Standing dead individuals and branching specimens with at least one trunk having a $\mathrm{CBH}$ equal or greater than $15 \mathrm{~cm}$ were also included in the sample. The botanical specimens collected were identified and deposited in the Herbarium of the State University of Maringá (HUM). The phytosociological parameters were calculated and analyzed using the program FITOPAC ${ }^{\circledR}$. The following parameters were calculated: absolute and relative density, dominance, and frequency. From these data were obtained the importance value (IV), equitability, and Shannon-Weaner diversity index $\left(\mathrm{H}^{\prime}\right)$ (Müller-Dombois \& Ellenberg, 1974; Matteucci \& Colma, 1982; Rodrigues, 1989).

The spatial distribution of the species was evaluated considering the transect delimited for the phytosociological analysis as divided into 18 zones, each consisting of two $15 \times 10 \mathrm{~m}$ plots totaling $300 \mathrm{~m}^{2}$ (Fig. 2). The data obtained in the phytosociological evaluation for the species with highest densities among the sucessional categories (pioneer, secondary, and climax) were considered. For better evaluation of the structure of the forest remnant, dead individuals were included in the analyses. Plant strategies were evaluated by classifying all species as pioneer, secondary, and climax, according to Budowski (1965), Kageyama et al. (1992) and personal field observations. For each category, the sum of the importance values (IV) obtained for the species was considered.

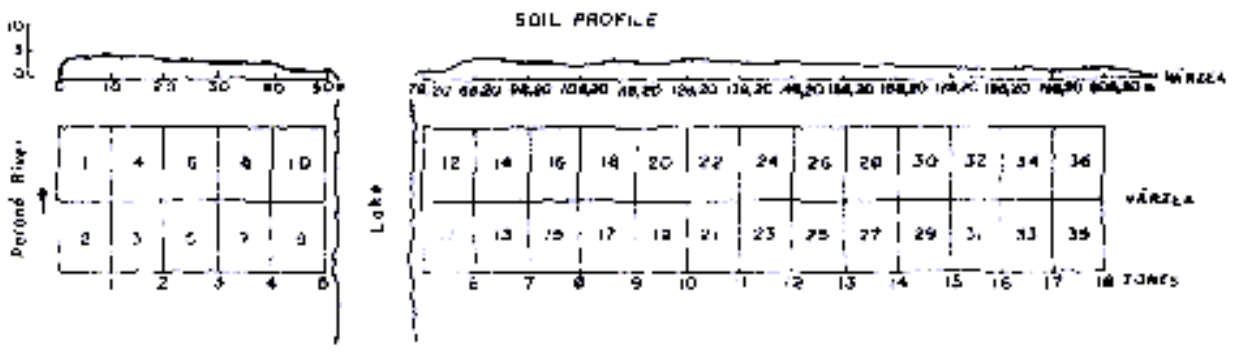

Figure 2 - Soil profile and distribution of the plots and zones along the transect.

\section{RESULTS AND DISCUSSION}

Terrain characteristics: the area topographic profile showed an alluvial shoreline dike with its base in the bed of the Paraná River, rising to a height of $3.95 \mathrm{~m}$ (measured on 20 September
1996). The profile then sloped downwards through the forest to the lake, which was at the same level as the river. Beginning on the opposite shore of the lake was another elevated area with maximum height $3.56 \mathrm{~m}$, which then sloped down again toward the varzea (Fig. 2). The soil of the dike 
was alluvial, not hydromorphic, little consolidated, and sandy. In the area near the lake the soil was alluvial, hydromorphic silt-clay gley. The soils of the region originated from Quaternary deposits (Eletrosul, 1989). According to Stevaux (1994), the deposits of the shoreline dike have a facies profile formed by a sandy basal unit, a muddy middle unit, and an upper unit with increasing grain size and thickness. The areas near the lake and the várzea, consisted of a typical floodplain deposit with sediments originating from marsh and oxbow lake environments.

Composition and vegetation structure: for the phytosociological analysis, 795 individuals were sampled, of which 32 were dead. The 763 living individuals were distributed among 28 families, 41 genera, and 47 species. The family of one individual could not be determined (Table 1). The total density was 1,472 individuals per hectare, with a volume of $175.79 \mathrm{~m}^{3}$, equivalent to 324.07 $\mathrm{m}^{3} /$ ha. The total basal area for the area sampled was $14.51 \mathrm{~m}^{2}$, equivalent to a basal area of 26.88 $\mathrm{m}^{2} /$ ha. The families with greatest species richness were the Mimosaceae (4), Lauraceae (4), Caesalpinaceae (3) and Myrtaceae (3). The families having the most individuals were the Cecropiaceae (142), Mimosaceae (99), Lauraceae (58), Meliaceae (55), and Sterculiaceae (54). Among the 28 families in the sample, these 5 were responsible for about half the individuals sampled $(51.32 \%)$. The families with highest importance values (IV) were the Cecropiaceae (55.57), Mimosaceae (36.96), Sterculiaceae (19.21), Caesalpinaceae (17.79) and Lauraceae (17.73). These 5 families accounted for $49.08 \%$ of the total IV.

The Shannon-Weaner diversity index $\left(\mathrm{H}^{\prime}\right)$ was 3.20 for species. This was the highest value yet found in phytosociological studies on the Upper Paraná River Floodplain. Assis (1991) found a value of 3.09, Souza-Stevaux et al. (1995) obtained a value of 2.51, Cislinski \& SouzaStevaux (1996), and Souza \& Monteiro (1996) 2.67. In general, these authors considered that the effects of the periodic river floods were the main factor accounting for these values.

The species with highest IV were Cecropia pachystachya (54.35), more than double that of the next higher, Inga uruguensis (21.09). Following these were Guazuma ulmifolia (18.49) and Peltophorum dubium (14.96). These four species were responsible for $36.29 \%$ of the total IV obtained. The remaining percentage was divided between dead individuals $(4.91 \%)$ and other 42 species. Souza-Stevaux \& Cislinski (1996) and Previdello et al. (1996) also found the highest values of IV for C. pachystachya, 50.45 and 142.31 respectively. Except for the study by Assis (1991), who calculated a low IV for $C$. pachystachya (0.64), this species was always found to be among the most important in phytosociological analyses performed in the region (Souza-Stevaux et al., 1995; Cislinski \& Souza-Stevaux, 1996).

The category of dead trees occupies fifth place among IV values. Assis (1991), in a study on the Upper Paraná River Floodplain, found this category at second place. He considered that human activities and exceptional floods were responsible for this index. Dead trees were at 13th place in the study carried out in the same region by Souza-Stevaux et al. (1995). Those authors considered that the climax stage of the forest that they studied accounted for this position.

The density of individuals per zone varied from 16 to 72 (Fig. 3). Zone 1 contained the highest density, followed by zones 5 and 8 (66 individuals each). The zone with the lowest number of individuals was 18. This low value was explainable by the location of zone 18 in a transitional area between the forest and the várzea.

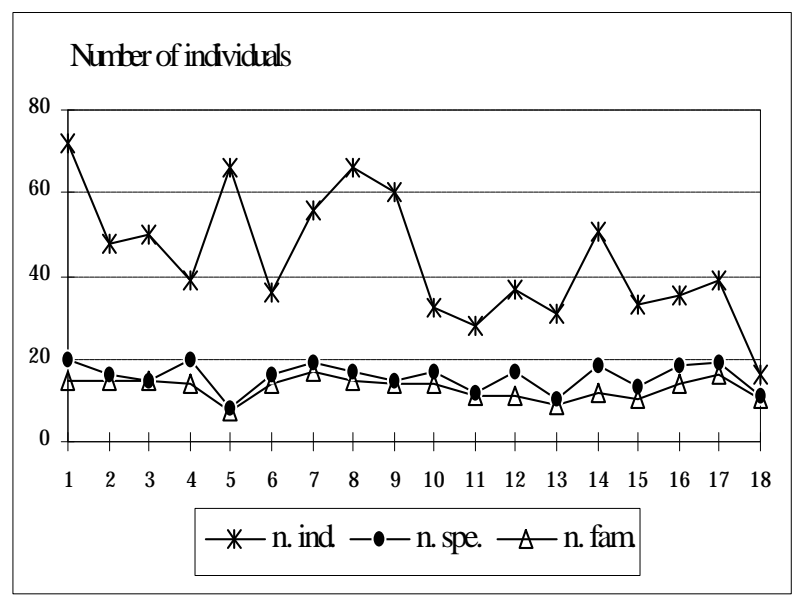

Figure 3 - Numbers of individuals (n. ind.), numbers of species (n. spe.), and numbers of families (n. fam.) for the transect zones.

The number of species per zone varied from 8 to 20. Zones 1 and 4 had the highest number of species, and zone 5 the lowest. For families, zone 
7 had the highest number (17), followed by zone 17 (16). In zone 3, all the 15 species sampled belonged to different families.

Values of the Shannon-Weaner diversity index $\left(\mathrm{H}^{\prime}\right)$ for the transect zones are shown in Fig. 4. The values per zone varied little; most were between 2.0 and 2.7, except for zone 5 with a quite low value of 1.1. In this zone, 66 individuals of 8 species occurred, including 39 individuals of $C$. pachystachya, 19 of Nectandra falsifolia, and the remaining 8 distributed among 6 species. The low diversity value for zone 5 is consistent with the values for equitability. Equitability varied between 0.83 and 0.97 for all the transect zones, the exception again being zone 5 which had the lowest value (0.54). Odum (1969) explained that a reduction in species diversity together with increased dominance by a single species leads to a decrease in equitability values. Zone 5 , near the shore of the lake, was composed of plots located at the lowest levels of the transect. The low values of diversity and equitability found there are probably because of the greater frequency of floods in that area. These frequent floods cause selection pressure, restricting the habitat niche to a few species adapted to these conditions. This occurs with $C$. pachystachya, a highly dominant species in this zone, whose adaptations include functional lenticels and adventitious roots.

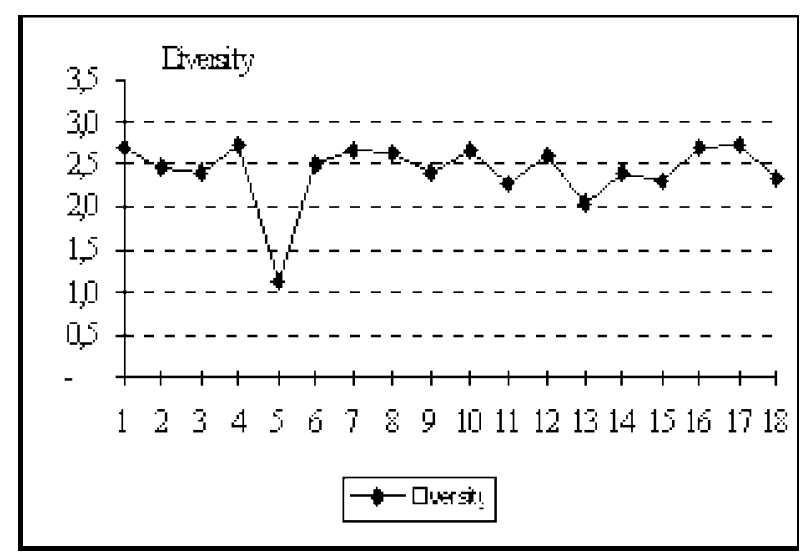

Figure 4 - Species diversity (Shannon-Weaner index, $\left.\mathrm{H}^{\prime}\right)$ for the transect zones.
Spatial distribution: the species selected for evaluation of species distribution were the pioneer Cecropia pachystachya; the secondary species Inga uruguensis, Guazuma ulmifolia and Peltophorum dubium; and the climax species Coussarea platyphylla, Unonopsis lindmanii and Piper tuberculatum (Fig. 5). Cecropia pachystachya appeared in all the transect zones, behaving as a generalist species. An exceptionally high total of 39 individuals, the highest concentration of a single species in any zone, was found in zone 5 next to the lake. Inga uruguensis and Guazuma ulmifolia did not appear to follow any distribution pattern, occurring along nearly the whole transect except for four zones. In contrast to Peltophorum dubium occurred in highest concentration in the zones west of the lake. The distribution of the climax species Coussarea platyphylla, Unonopsis lindmanni, and Piper tuberculatum indicated a general preference for locations less frequently inundated. These species occupied the higher parts of the transect and were absent from the lower sections near the lake (zones 4 and 5). 


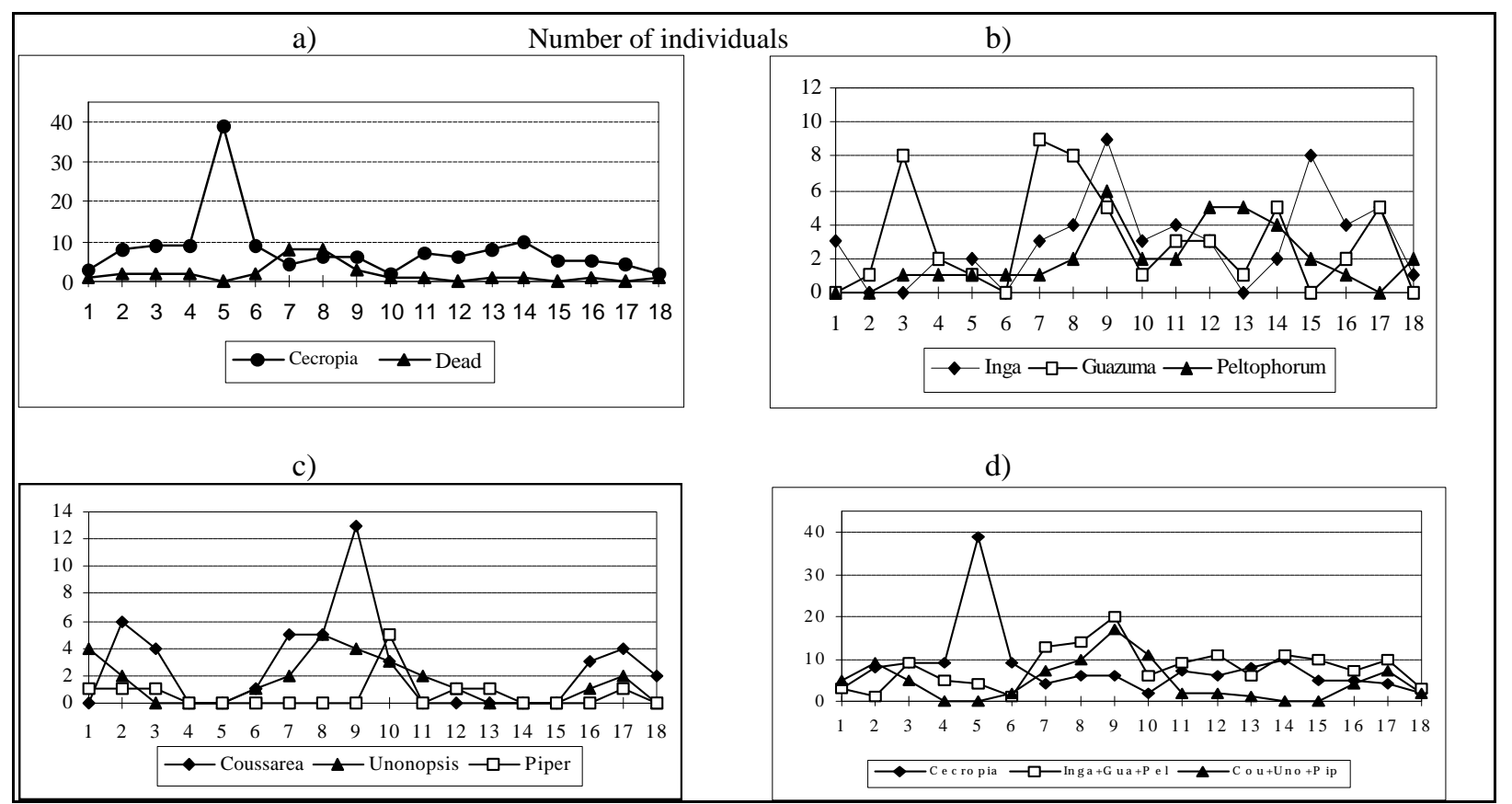

Figure 5 - Spatial distribution of selected species along the transect: a) Cecropia pachystachya and dead trees; b) Inga uruguensis, Guazuma ulmifolia and Peltophorum dubium; c) Coussarea platyphylla, Unonopsis lindmanii and Piper tuberculatum; d) C. pachystachya (Cecropia) (pioneer); sum of the species I. uruguensis + G. ulmifolia $+P$. dubium $(\mathrm{Inga}+\mathrm{Gua}+\mathrm{Pel})($ secondary) and C. platyphylla + U. lindmanii + P. tuberculatum $(\mathrm{Cou}+\mathrm{Uno}+$ Pip) (climax).

Phytosociological evaluation for the transect zones showed that in the lowest area of the soil profile (zone 5), which most frequently suffers the effects of flooding, no dead individual was found. The plots with the highest IV for dead trees were located in higher areas, i.e. the areas least subject to flooding (zones 7 and 8). This observation, allied to the fact that the majority of dead individuals were $C$. pachystachya, a pioneer, flood-adapted species, leads to the conclusion that probably the fifth position occupied by the category of dead trees is not a result of flooding from the river, but of natural sucessional processes.

Summing the occurrences of the species by sucessional category showed that pioneer and climax species are distributed inversely. That is, to the extent that pioneer specie increase, the occurrence of climax species diminishes, and vice versa. The secondary species show intermediate behavior in the area between the river and the lake, becoming most prominent and having the highest diversity west of the lake.

Sucessional stage: in relation to sucessional stage of the forest, summing the IV values of all the species sampled resulted in the highest value for secondary species, with $207.77(69.26 \%$ of the total), followed by the pioneer species with 54.78 (18.27\% of the total), and the climax species with 21.87 ( $7.29 \%$ of the total). The category of dead trees had an IV of 14.75 (4.91\% of the total IV). Two individuals of undetermined family and which therefore could not be included in any of the sucessional categories, had an IV of 0.83 $(0.27 \%$ of the total). Souza-Stevaux \& Cislinski (1996), in a study carried out in an area next to that of the present study, also found a larger IV value for secondary species of $165.01(55.00 \%$ of their total), followed by climax species with 60.73 (20.24\%), and pioneer species with 50.91 (16.97\%). The distribution along the transect zones (Fig. 6) showed a predominance of secondary species, zones 1 and 15 showing the highest values (IV of 241.41 and 246.65 respectively). Zone 5, next to the lake, had the lowest value for this category (153.50), quite near the value for pioneer species (146.51). In this zone and in zone 15 , only species of these two categories occurred. Climax species also did not occur in zone 4. 


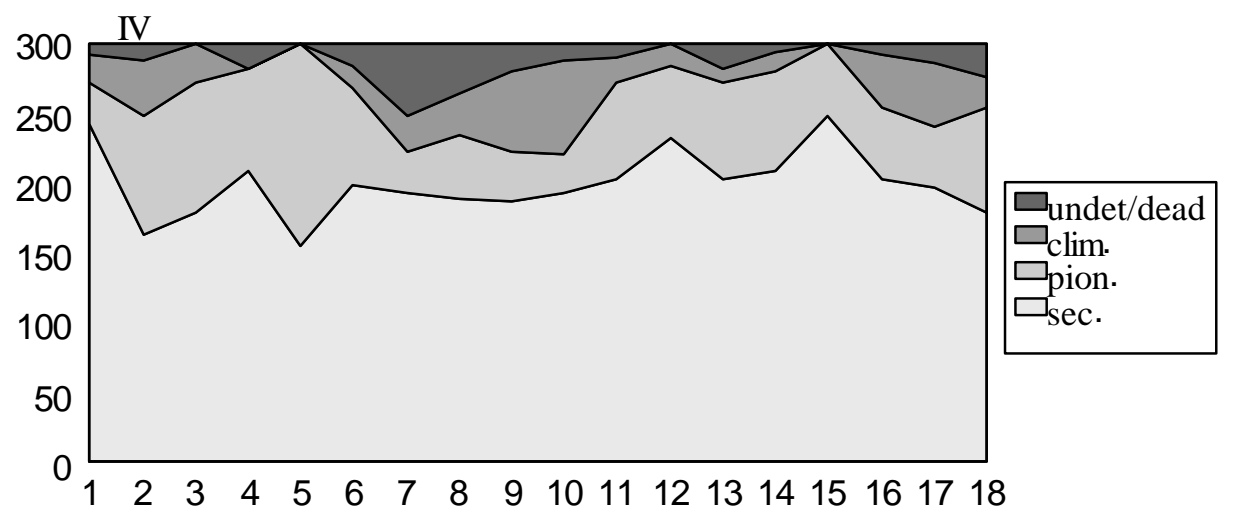

Figure 6 - Distribution of IV for the secondary species (sec.), pioneer species (pion.), climax species (clim.), and undetermined/dead species (undet./dead) along the transect.

Neiff (1986), studying the vegetation of islands of the Paraná River in Argentina and Paraguay, warned that it is inappropriate to characterize vegetation without considering its temporal variability. Neiff (1986) considered two patterns of temporal variability: one which corresponds to elevated areas where the vegetation is little influenced by fluvial hydrodynamics, and another in which the hydrological and sediment dynamics are the most influential factor on vegetation dynamics. Evaluation of the distribution of the species between the shoreline dike (zones 2 and 3 ) and the low area next to the lake (zones 4 and 5) revealed important differences. On the dike, three species of different sucessional categories had the highest IVs: the pioneer Cecropia pachystachya (68.69, with 17 individuals), the secondary species Sloanea guianensis (25.83, 8 individuals), and the climax species Coussarea platyphylla (12.49, 10 individuals). In the area next to the lake, the species with highest IV was $C$. pachystachya (94.67, 48 individuals), followed by two secondary species, Nectandra falsifolia $(43.34,21$ individuals) and Sapindus saponaria (25.18, 2 individuals). No climax species occurred in that area. Species distribution could be related to the spatial variation of the environment which they occupied. The shoreline dike averaged $3.15 \mathrm{~m}$ above the level of the river, with nonhydromorphic, sandy alluvial soil. In contrast, the low area next to the lake had a mean height of $1.58 \mathrm{~m}$ above the river level and its soil was composed of hydromorphic, clayey alluvial gley. Odum (1971) considered that the fundamental environmental parameters used to assist in delineating vegetation, were climate, lithology, relief, and soil. The degree of influence that these factors exercised on the vegetation was extremely variable, in some circumstances inhibiting, in others stimulating plant development. Vegetational differentiation remained closely related to variations in certain attributes of the soil. The height, diameter, and volume of the vegetation of the two environments were similar. The differences in the other parameters analyzed were probably related to the distribution of the species in physical space and to their sucessional characteristics. This demonstrated that the process of ecological succession was more dynamic on the shoreline dike than in the lower area next to the lake.

In the lower area, species distribution was closely related to the physical characteristics of the environment, mainly in regard to the soil level relative to the river, which determined the level of the water table and the frequency of floods. This relationship demonstrated that the process of succession was governed by these characteristics. According to Odum (1969), in the process of ecological succession, the physical environment determined the pattern, rate of change, and frequently the factors limiting development. Alteration of the physical characteristics of the soil was a process involving alluvial deposits that led to elevation of soil levels, and was a limiting factor for vegetation development over the long term. Therefore it could be supposed that, in spite of the predominance of a pioneer species, Cecropia pachystachya, and of the absence of 
climax species, the vegetation present in low-lying

the concepts of Odum (1971).

areas was in an edaphic climax stage, according to

Table 1 - Relationship of the living species and dead individuals in a remnant of the Semideciduous Seasonal Alluvial Forest on the Upper Paraná River Floodplain, Brazil, to their respective number registered (NR); sucessional category (SC); phytosociological parameters: $\mathrm{n}=$ number of individuals, $\mathrm{p}=$ number of plots where the species occurred, $\mathrm{RD}=$ relative density, $\mathrm{RDo}=$ relative dominance, $\mathrm{RF}=$ relative frequency, and $\mathrm{IV}=\mathrm{importance}$ value.

\begin{tabular}{|c|c|c|c|c|c|c|c|c|}
\hline SPECIE AND DEAD TREE & NR & SC & $\mathbf{n}$ & $\mathbf{p}$ & RD & RDo & $\mathbf{R F}$ & IV \\
\hline Cecropia pachystachya Trec. & 3569 & $\mathrm{P}$ & 142 & 32 & 17.86 & 27.86 & 8.63 & 54.35 \\
\hline Inga uruguensis Hook et Arn. & 3573 & S & 53 & 22 & 6.67 & 8.49 & 5.93 & 21.09 \\
\hline Guazuma ulmifolia Lam. & 3564 & S & 54 & 19 & 6.79 & 6.57 & 5.12 & 18.49 \\
\hline Peltophorum dubium (Spreng.) Taub. & 3555 & S & 36 & 18 & 4.53 & 5.58 & 4.85 & 14.96 \\
\hline Dead trees & & - & 32 & 16 & 4.03 & 6.41 & 4.31 & 14.75 \\
\hline Albizzia hassleri (Chodat) Burr. & 3557 & $\mathrm{~S}$ & 35 & 19 & 4.40 & 4.22 & 5.12 & 13.74 \\
\hline Coussarea platyphylla M. Arg. & 3579 & $\mathrm{C}$ & 46 & 15 & 5.79 & 1.40 & 4.04 & 11.23 \\
\hline Sloanea guianensis (Aubl.) Benth. & 3552 & S & 28 & 11 & 3.52 & 3.50 & 2.96 & 9.99 \\
\hline Guarea guidonia (L.) Sleumer & 3525 & S & 28 & 13 & 3.52 & 2.84 & 3.50 & 9.96 \\
\hline Eugenia florida DC. & 3528 & S & 28 & 15 & 3.52 & 1.38 & 4.04 & 8.94 \\
\hline Unonopsis lindmanii R.G.Fries & 3533 & $\mathrm{C}$ & 27 & 14 & 3.40 & 1.28 & 3.77 & 8.45 \\
\hline Triplaris americana $\mathrm{L}$. & 3577 & S & 20 & 12 & 2.52 & 2.54 & 3.23 & 8.29 \\
\hline Trichilia palida $\mathrm{Sw}$. & 3572 & S & 27 & 11 & 3.40 & 1.58 & 2.96 & 7.94 \\
\hline Ruprechtia laxiflora Meis. & 3984 & $\mathrm{~S}$ & 23 & 10 & 2.89 & 1.59 & 2.70 & 7.18 \\
\hline Tabernaemontana catharinensis A. DC. & 3554 & S & 19 & 13 & 2.39 & 0.91 & 3.50 & 6.81 \\
\hline Galesia integrifolia (Spreng.) Harms. & 3576 & S & 16 & 6 & 2.01 & 3.04 & 1.62 & 6.67 \\
\hline Ocotea diospyryfolia (Meissn.) Mez. & 3556 & S & 17 & 12 & 2.14 & 1.22 & 3.23 & 6.59 \\
\hline Nectandra falcifolia (Nees.) Cast. ex Mart. & 3571 & $\mathrm{~S}$ & 23 & 6 & 2.89 & 1.68 & 1.62 & 6.19 \\
\hline Pouteria torta (Mart.) Radlk. & 3995 & $\mathrm{~S}$ & 12 & 7 & 1.51 & 2.50 & 1.89 & 5.90 \\
\hline Nectandra cissifolia Ness. & 3998 & $\mathrm{~S}$ & 15 & 12 & 1.89 & 0.70 & 3.23 & 5.82 \\
\hline Protium heptaphyllum Aubl. March. & 3975 & S & 15 & 9 & 1.89 & 1.25 & 2.43 & 5.56 \\
\hline Casearia gossypiosperma Briquet & 3536 & S & 16 & 10 & 2.01 & 0.46 & 2.70 & 5.16 \\
\hline Sapindus saponaria $\mathrm{L}$. & 3562 & S & 6 & 5 & 0.75 & 2.88 & 1.35 & 4.98 \\
\hline Allophyllus edulis (A.St. Hil.) Radlk & 3989 & $\mathrm{~S}$ & 11 & 8 & 1.38 & 0.44 & 2.16 & 3.98 \\
\hline Piper tuberculatum Jacq. & 4001 & $\mathrm{C}$ & 11 & 8 & 1.38 & 0.36 & 2.16 & 3.90 \\
\hline Sloanea garckeana K.Schum. & 3997 & S & 5 & 3 & 0.63 & 2.44 & 0.81 & 3.88 \\
\hline Spondias lutea $\mathrm{L}$. & 3553 & S & 5 & 5 & 0.63 & 1.83 & 1.35 & 3.81 \\
\hline Zygia cauliflora (Willd.) Killip. & 3559 & S & 8 & 7 & 1.01 & 0.85 & 1.89 & 3.74 \\
\hline Parapiptadenia rigida (Benth.) Brenan & 3574 & S & 3 & 3 & 0.38 & 0.80 & 0.81 & 1.98 \\
\hline Celtis iguanaea (Jacq.) Sargent. & 3965 & S & 4 & 2 & 0.50 & 0.56 & 0.54 & 1.60 \\
\hline Callophylum brasiliensis Camb. & 3570 & $\mathrm{~S}$ & 3 & 3 & 0.38 & 0.26 & 0.81 & 1.45 \\
\hline Hexachlamys itatiaiae Mattos & 3969 & $\mathrm{~S}$ & 3 & 2 & 0.38 & 0.43 & 0.54 & 1.34 \\
\hline Rollinia emarginata Schl. & 3544 & $\mathrm{~S}$ & 3 & 3 & 0.38 & 0.08 & 0.81 & 1.27 \\
\hline Nectandra mollis (HBK) Nees. & 3539 & S & 3 & 3 & 0.38 & 0.07 & 0.81 & 1.25 \\
\hline Cordia selowiana Cham. & 3537 & S & 2 & 2 & 0.25 & 0.41 & 0.54 & 1.20 \\
\hline Copaifera langsdorfii Desf. & 3526 & S & 1 & 1 & 0.13 & 0.69 & 0.27 & 1.08 \\
\hline Apuleia leiocarpa (Vog.) Macbr. & 3555 & S & 2 & 1 & 0.25 & 0.46 & 0.27 & 0.98 \\
\hline Psidium guajava $\mathrm{L}$. & 3969 & $\mathrm{~S}$ & 2 & 2 & 0.25 & 0.05 & 0.54 & 0.84 \\
\hline Undetermined & WR & $?$ & 2 & 2 & 0.25 & 0.04 & 0.54 & 0.83 \\
\hline Pouteria glomerata (Miq.) Radlk. & 3563 & $\dot{S}$ & 2 & 2 & 0.25 & 0.03 & 0.54 & 0.82 \\
\hline Chusquea selowii Rupr. & 3700 & S & 1 & 1 & 0.13 & 0.15 & 0.27 & 0.54 \\
\hline Croton urucurana Baill. & 4004 & $\mathrm{P}$ & 1 & 1 & 0.13 & 0.04 & 0.27 & 0.43 \\
\hline Citrus limom (L.) Burn & 3527 & S & 1 & 1 & 0.13 & 0.03 & 0.27 & 0.43 \\
\hline Solanum granuloso-leprosum Dunal & 3582 & $\mathrm{P}$ & 1 & 1 & 0.13 & 0.03 & 0.27 & 0.43 \\
\hline Citrus sp & 3971 & $\mathrm{~S}$ & 1 & 1 & 0.13 & 0.03 & 0.27 & 0.42 \\
\hline Machaonia brasiliensis (Hoff. ex Schul) Cham. et Schl. & 3549 & $\mathrm{~S}$ & 1 & 1 & 0.13 & 0.03 & 0.27 & 0.42 \\
\hline Aegiphilla candelabrum Briq. & 4696 & S & 1 & 1 & 0.13 & 0.03 & 0.27 & 0.41 \\
\hline
\end{tabular}

WR = Without Register P = Pioneer; $\mathrm{S}=$ Secondary; $\mathrm{C}=$ Climax

\section{CONCLUSIONS}

The difficulty of understanding vegetation dynamics in tropical forests has been recognized by many investigators. This difficulty is greater in unstable areas subject to continuous processes of change, such as the Upper Paraná River Floodplain. In such locations, the vegetation 
reflects the instability of the environment. Hydrodynamic and sedimentary processes, as previously recognized by Neiff (1986), were the most important factors in the establishment and development of vegetation. It were these processes that led to the formation and evolution of the soil substrate in which the vegetation established itself. The plants thus reflected local spatial variability in their dynamics, structure, and distribution pattern. These results, therefore, indicated that revegetation of riparian areas of this region should be preceded by an accurate evaluation of the local environment. Such an evaluation should emphasize the distribution of the vegetation according to physical characteristics of the soil.

\section{RESUMO}

O objetivo deste trabalho foi analisar a estrutura, o padrão de distribuição e a dinâmica de espécies arbóreas de um fragmento remanescente da Floresta Estacional Semidecidual Aluvial na planície de inundação do alto rio Paraná frente às variações espaciais, principalmente em relação ao solo e às características topográficas. A área de estudo compreendeu um transecto desde a margem do rio Paraná até a várzea, passando por uma lagoa. Foram analisadas fitossociologicamente 36 parcelas de $150 \mathrm{~m}^{2}$ e realizadas subanálises em faixas de $300 \mathrm{~m}^{2}$. Foram levantadas as características do solo, o perfil topográfico da área e suas relações com a vegetação. Os processos hidrodinâmicos e hidrossedimentológicos mostram ser os fatores de maior importância no estabelecimento e sucessão da vegetação, determinando a seleção de espécies e a formação e evolução do substrato, refletindo assim, na dinâmica, na estrutura e no padrão de distribuição da vegetação a variabilidade espacial local.

\section{REFERENCES}

Agostinho, A. A.; Zalewski, M. (1996). A planície alagável do alto rio Paraná: Importância $e$ preservação. Maringá - PR, EDUEM.

Assis, M. A. (1991). Fitossociologia de um remanescente de mata ciliar do rio Ivinheima $(M S)$. Dissertação de Mestrado em Biologia Vegetal.
Campinas-SP, Brasil, Instituto de Botânica. Universidade Estadual de Campinas.

Budowski, G. (1965). Distribution of tropical american rain forest species in the light of sucessional processes. Turrialba (C.R.) 15: 40-42.

Campos, J. B.; Costa-Filho, L. V. (1994). Proposta técnica de implantação da área de proteção ambiental do Arquipélago de Ilha Grande. CuritibaPr, SEMA/IAP. 54p.

Campos, J.B.; Souza, M.C. (1997). Vegetação. In: Vazzoler, A.E.A.M.; Agostinho, A.A.; Hahn, N.S. (Eds.) A Planície de Inundação do Alto Rio Paraná: aspectos físicos, biológicos e socioeconômicos. Maringá : EDUEM : Nupélia, 1997. pp. 331-342

Cislinski, J.; Souza-Stevaux, M. C. (1996). Fitossociologia de um remanescente de mata ciliar da margem do rio Baía, Taquaruçu, MS. In: CONGRESSO NACIONAL DE BOTÂNICA (47., 1996. Nova Friburgo, RJ-BRA). Resumos... Nova Friburgo, RJ. p.211.

Eletrosul - Centrais Elétricas do Sul do Brasil. (1986). Ilha Grande - A vegetação da área de influência do reservatório da usina hidrelétrica de Ilha Grande $(P R / M S)$. Florianópolis.

Embrapa. (1984). Serviço Nacional de Levantamento e Conservação de Solos, Rio de Janeiro, RJ. Levantamento e reconhecimento dos solos do Estado do Paraná. Curitiba. 2v.:il. (Embrapa - SNLCS. Boletim técnico; n. 27).

FUEM/CIAMB-PADCT. (1993). Estudos ambientais da planície de inundação do rio Paraná, no trecho compreendido entre a foz do rio Paranapanema e o reservatório de Itaipu. Maringá, Fundação Universidade Estadual de Maringá, 1993. 3v. (Relatório de pesquisa - Apoio PADCT-CIAMB).

Fundação SOS Mata Atlântica/INPE. (1992/93). Atlas da evolução dos remanescentes florestais $e$ ecossistemas associados do domínio da Mata Atlântica no período de 1985 - 1990. São Paulo, INPE. 20 p.

IBGE - Fundação Instituto Brasileiro de Geografia e Estatística. (1992). Manual técnico da vegetação brasileira. Rio de Janeiro, IBGE. 92p. (Série Manuais Técnicos em Geociências; 1).

Ipardes. (1992). Diagnóstico para a implantação de políticas para o setor florestal no Paraná. Curitiba PR, Fundação Ipardes. 48p.

Kageyama, P. Y.; Equipe técnica da CESP. (1992). Recomposição da vegetação com espécies arbóreas nativas em reservatórios de usinas hidrelétricas da CESP. Série Técnica IPEF, Piracicaba (BRA) 8 (25): $1-43$.

Maack, R. (1981). Geografia física do Estado do Paraná. Rio de Janeiro, J. Olympio Ed. $2^{\text {a }}$ edição. 
Mateucci, S.; Colma, A. (1982). Metodologia para el estudio de la vegetación. Washington D.C., Secretaria general de la Organización de los Estados Americanos - OEA.

Müeller-Dombois, D.; Ellenberg, H. (1974). Aims and methods of vegetation ecology. New York, John Wiley \& Sons.

Neiff, J. J. (1986). Las grandes unidades de vegetacion y ambiente insular del rio Paraná en el tramo Candelaria - Ita Itabe. Revista de la Associacion de Ciencias Naturales del Litoral (Argentina) 17(11): 713.

Odum, E. P. (1969). The Strategy of ecosystem development. Science (New York) 164 (3877): 262270.

Odum, E. P. (1971). Fundamentos de Ecologia. 4 ed. Lisboa, Fund. Calouste Gulbenkian.

Previdello, M. E.; Souza, M. C.; Romagnolo, M. B. (1996). Análise da estrutura da mata ciliar em áreas de colonização natural, ilha Mutum, rio Paraná, município Taquaruçu, MS. In: CONGRESSO NACIONAL DE BOTÂNICA (47., 1996. Nova Friburgo, RJ-BRA). Resumos... Nova Friburgo, RJ. p.199.

Rodrigues, R. R. (1989). Análise estrutural das formações florestais ripárias. In: Barbosa, L. M. (coord.). Anais do Simposio sobre Mata Ciliar. Campinas, SP, Fund. Cargill. pp. 99-119.
Romagnollo, M. B.; Souza-Stevaux, M. C.; Ferrucci, M. S. (1994). Sapindaceae da planície de inundação do trecho superior do rio Paraná. Revista UNIMAR, Maringá (BRA) 16 (suplemento 3):61-81.

Souza, M. C.; Monteiro, R. (1996). Análise do remanescente florestal, mata do Araldo, da margem do rio Paraná, município de Porto Rico, PR. In: CONGRESSO NACIONAL DE BOTÂNICA (47., 1996. Nova Friburgo, RJ-BRA). Resumos..., Nova Friburgo, RJ. p.199.

Souza-Stevaux, M. C., Romagnolo, M. B.; Previdello, M. E. (1995). Florística e fitossociologia de um remanescente florestal às margens do rio Paraná, Munic. de Porto Rico. In: CONGRESSO NACIONAL DE BOTÂNICA (46., 1995. Ribeirão Preto, SP-BRA). Resumos... Ribeirão Preto, SP. p.325.

Souza-Stevaux, M. C; Cislinski, J. (1996). Vegetação de uma área do Trecho Superior do rio Paraná e seu potencial para reflorestamento. In: SEMINÁRIO REGIONAL DE ECOLOGIA (8., 1996. São Carlos, SP-BRA). Resumos... UFSCar, São Carlos, SP. p.97.

Stevaux, J. C. (1994). Geomorfologia, sedimentologia e paleoclimatologia do alto curso do rio Paraná (Porto Rico, Pr.). Boletim Paranaense de Geociências (BRA) 42:97-112. 